\title{
PROBLEMATIKA DALAM PEMBELAJARAN BAHASA INGGRIS DI STAIN BENGKALIS
}

\author{
Roinah \\ STAIN BENGKALIS \\ roirsanlbs@gmail.com
}

\begin{abstract}
Abstrak
Penelitian ini bertujuan untuk mengetahui gambaran permasalahan pembelajaran bahasa Inggris dilihat dari segi faktor internal dan segi faktor eksternal pada mahasiswa STAIN Bengkalis. Peneliti merumuskan permasalahan berupa: a) bagaimana gambaran permasalahan pembelajaran bahasa Inggris dilihat dari segi faktor internal pada mahasiswa STAIN Bengkalis?; b) bagaimana gambaran permasalahan pembelajaran bahasa Inggris dilihat dari segi eksternal pada mahasiswa STAIN Bengkalis?. Sampel penelitian berjumlah 310 responden. Responden dipilih secara acak dengan teknik simple random sampling. Instrumen penelitian yang digunakan yaitu kuisioner. Sebelum pengambilan data, instrumen sudah diuji validas dan reabilitas guna kevalitan data yang dikumpulkan. Hasil penelitian menunjukkan; gambaran permasalahan pembelajaran bahasa Inggris dilihat dari segi faktor internal pada mahasiswa STAIN Bengkalis yakni dipengaruhi oleh (1) sikap terhadap belajar; (2) motivasi belajar; (3) konsentrasi belajar; (4) intelegensi dan keberhasilan belajar; (5) kebiasaan belajar; (6) kemampuan mengolah bahan belajar dan (7) kemampuan berprestasi. Gambaran permasalahan pembelajaran bahasa Inggris dilihat dari segi faktor eksternal pada mahasiswa STAIN Bengkalis yakni dipengaruhi oleh pendidik yaitu dosen yang mengajar bahasa inggris yang kurang bervariasi dalam mengajar. Responden sangat menyadari bahwa belajar bahasa inggris merupakan satu kebutuhan karena bahasa inggris menjadi bahasa internasional. Dari kuisioner yang disebar ke responden faktor internal lebih dominan dalam kesuksesan dalam belajar.
\end{abstract}

Key words : Problematika; pembelajaran; bahasa inggris.

\begin{abstract}
This study aims to describe the problem of learning English in terms of internal factors and external factors in STAIN Bengkalis students. The researcher formulated the problem in the form of: a) how the description of the problem of learning English in terms of internal factors in STAIN Bengkalis students ?; b) how is the description of English learning problems seen externally in STAIN Bengkalis students? The research sample amounted to 310 respondents. Respondents were chosen randomly by simple random sampling technique. The research instrument used was a questionnaire. Before data collection, the instrument has been tested for validity and reliability for the validity of the data collected. The results of the study show; the picture of the problem of learning English is seen in terms of internal factors in STAIN Bengkalis students which are influenced by (1) attitudes towards learning; (2) learning motivation; (3) concentration of learning; (4) intelligence and learning success; (5) study habits; (6) ability to process learning materials and (7) ability to achieve. The description of English learning problems seen in terms of external factors in STAIN Bengkalis students is influenced by educators, namely lecturers who teach English that are less varied in teaching. Respondents were very
\end{abstract}




\section{Roinah}

aware that learning English was a necessity because English became an international language. From the questionnaire distributed to respondents the internal factors are more dominant in success in learning.

Key words: Problems; learning; English.

\section{A. Pendahuluan}

Bahasa merupakan alat untuk berkomunikasi. Melalui penguasaan bahasa yang baik, maka akan terjalin komunikasi yang baik pula. Pada era distrupsi, penguasaan bahasa sangat dibutuhkan, salah satunya bahasa inggris. Bahasa inggris diajarkan mulai dari level sekolah menengah sampai perguruan tinggi. Ini bertujuan agar siswa/mahasiswa mumpuni dalam menguasai bahasa inggris. Untuk meraih target tersebut, mahasiswa mengalami berbagai kendala, seperti rendahnya penguasaan kosakata dalam bahasa inggris, kurangnya motivasi dalam pembelajaran bahasa inggris, sulit membangun komunikasi dalam menggunakan bahasa inggris, dan faktor lainnya. Permasalahan yang dihadapi membuat mahasiswa sulit untuk beradaptasi dengan pembelajaran bahasa inggris.

Masalah merupakan kesenjangan antara teori dan kenyataan yang diharapkan. Kendala tersebut harus mampu diselasaikan dengan bijaksana agar tidak ada kesenjangan antara teori dan praktek. Bahasa Inggris merupakan salah satu bahasa internasional yang digunakan untuk berkomunikasi. Materi bahasa Inggris telah diajarkan dari bangku sekolah hingga tingkat perguruan tinggi. Sejatinya, semakin lama satu materi diajarkan seharusnya semakin banyak yang mereka dapatkan khususnya dalam pelajaran bahasa Inggris. Akan tetapi harapan tidak sesuai dengan kenyataan, dimana banyak mahasiswa yang masih berhadapan dengan berbagai masalah yang berhubungan dengan bahasa Inggris.

Di era infromasi yang serba cepat ini, nampaknya tak cukup bagi kita hanya menguasai bahasa daerah dan bahasa Indonesia saja. Setidaknya, satu bahasa asing harus dikuasai, yakni Bahasa Inggris. Secara sederhana istilah pembelajaran sebagai upaya untuk membelajarkan seseorang atau kelompok orang melalui berbagai upaya dan berbagai strategi, metode dan pendekatan kearah pencapaian tujuan yang telah direncanakan. 
Oemar Hamalik mengartikan pembelajaran yaitu suatu kombinasi yang tersusun meliputi unsur-unsur manusiawi, material, fasilitas, perlengkapan dan prosedur yang saling mempengaruhi dalam mencapai tujuan belajar.Pembelajaran bahasa Inggris sudah berlangsung sejak lama. Sejak masa Kemerdekaan Indonesia. Berbagai kurikulum dan metode telah diterapkan dan dikembangkan untuk meningkatkan kemampuan peserta didik dalam menguasai bahasa Inggris. Walaupun demikian, hasilnya masih belum dirasakan maksimal dalam membuat peserta didik dapat berkomunikasi dengan baik melalui bahasa tersebut. Berbagai masalah dan faktor yang melatarbelakangi mengapa hasil yang dicapai belum sesuai dengan yang diharapkan. Salah satu cara pemerintah dalam meningkatkan kemampuan peserta didik dalam berbahasa Inggris adalah memperkenalkan Bahasa Inggris lebih dini, yaitu dimulai dari sekolah dasar.

Belajar bahasa asing dalam hal ini bahasa Inggris akan sangat berguna bagi diri kita. Potensi dan kemampuan diri akan semakin bertambah. Tentu saja semua ini akan memberikan hasil yang baik bagi kehidupan kita. Salah satu yang berpengaruh adalah kurangnya percaya diri. Banyaknya kosakata baru dan struktur kalimat yang berbeda dengan bahasa Indonesia, membuat banyak peserta didik yang malas. Ketakutan ini kemudian membuat mereka tidak suka. Akibatnya mereka sulit menguasai bahasa Inggris.

Meskipun berbagai cara telah dilakukan untuk meningkatkan minat belajar mahasiswa dalam materi Bahasa Inggris, namun permasalahan banyak ditemui di lapangan. Untuk itu perlu diadakan penelitian tentang problematika yang dihadapi oleh mahasiswa dalam pembelajaran Bahasa Inggris.

Peneliti dapat menjabarkan gejala-gejala dari masalah yakni: a) mahasiswa tidak mampu berkomunikasi dengan bahasaInggris baik lisan dan tulisan; b) mahasiswa kurang penguasaan kosakata bahasaInggris; c) mahasiswa tidak suka untuk belajar bahasaInggris; d) mahasiswa tidak mampu membangun kalimat bahasa inggris dengan baik dan benar secara struktur kalimat; e) mahasiswa kurang mampu dalam mengidentifikasi informasi dari sebuah teks yang dibaca. 


\section{B. Pembahasan}

\section{Peran Bahasa Inggris dalam dunia pendidikan}

Sekarang kita berada di zaman modern dimana semuanya telah berkembang pesat. Begitupun dengan manusianya, dituntut agar dapat memiliki kemampuan agar dapat mengikuti perkembangan zaman yang serba modern, salah satunya dengan mengembang kemampuan dalam berbahasa Inggris. Bahasa Inggris adalah bahasa yang telah ditetapkan menjadi bahasa dunia. Jadi dengan bisa berbahasa Inggris kita bisa dengan mudah berkomunikasi dengan orang lain di seluruh dunia.Di Indonesia sendiri telah menerapkan belajar berbahasa Inggris sebagai standar kelulusan mulai dari sekolah dasar hingga perguruan tinggi. Hal tersebut tentu sangat bermanfaat mengingat pentingnya mempunyai kemampuan untuk berbahasa Inggris. Contoh, jika pelajar Indonesia ingin melanjutkan kuliahnya di luar negeri salah satu syaratnya yaitu bisa berbahasa Inggris.

Bahasa memiliki peranan yang sangat penting dalam berkomunikasi. Selain bahasa ibu yang sudah kita miliki, banyak bahasa asing yang menarik untuk dipelajari seperti bahasa Mandarin, Jepang, Perancis, Jerman, dan lain-lain. Namun, harus diakui bahwa dari berbagai macam bahasa asing tesebut, Bahasa Inggris tetap menjadi bahasa asing yang banyak dipilih untuk dipelajari. Mengapa demikian?;

Pertama, bahasa Inggris adalah bahasa internasional. Ini terkait dengan sejarah di mana bangsa Inggris dahulu memiliki banyak jajahan sehingga secara otomatis bahasa mereka akan tersebar di daerah-daerah jajahan milik bangsa Inggris.

Kedua, bahasa Inggris adalah bahasa universal, bahasa pemersatu. Even-even internasional seperti olahraga, konferensi, pertemuan antar negara Bahasa Inggris dijadikan sebagai bahasa utama. Bahasa Inggris juga dijadikan sebagai bahasa standar di bidang pariwisata dan bidang transportasi udara dan laut.

Ketiga, investasi, dengan memiliki kemampuan berbahasa Inggris akan sangat berguna dalam bidang pendidikan (beasiswa sekolah ke luar negeri, pertukaran pelajar, pemahaman materi belajar di sekolah), pergaulan pun 
menjadi lebih luas. Bahasa Inggris juga bermanfaat sebagai nilai tambah dalam dunia pekerjaan.

\section{Kenapa Bahasa Inggris itu Penting?}

Ada beberapa alasan, kenapa bahasa Inggris itu penting yakni:

\section{a. Kesempatan mendapatkan pekerjaan}

Salah satu alasan paling penting dalam mempelajari Bahasa Inggris salah satunya adalah kesempatan untuk mendapat pekerjaan yang lebih layak terbuka lebar. Dengan mempunyai kemampuan dalam berbicara menggunakan dua bahasa, tentu hal itu akan menjadi nilai tambah pada diri kita. Selain itu, kita pun akan dapat mendapatkan karier di jenjang internasional jika kemampuan berbahasa Inggris kita sangat baik.

\section{b. Bahasa Inggris adalah bahasa yang umum}

Ketika mengunjungi negara lain di seluruh penjuru dunia, tentu kita tidak memahami bahasa setempat. Tapi, karena Bahasa Inggris merupakan bahasa yang umum, sebagai orang asing di suatu wilayah kita bisa menggunakan Bahasa Inggris untuk berkomunikasi.

\section{c. Kesempatan kerja}

Fasih dalam berbahasa Inggris akan menjadi nilai tambah saat mencari pekerjaan karena kita bisa berbicara dua bahasa. Bahkan, kita bisa mendapatkan karier internasional jika kemampuan berBahasa Inggris kita sangat baik.

\section{d. Inovasi dan perkembangan ekonomi}

Selain China, Amerika masih menjadi negara yang menguasai perkembangan inovasi dan ekonomi dunia. Dan Bahasa Inggris banyak digunakan di kedua bidang tersebut.

\section{e. Bahasa Inggris sebagai bahasa adaptasi}

Setiap negara yang pernah dijajah dipengaruhi oleh Bahasa Inggris. Oleh karena itu, Bahasa Inggris biasa diadaptasi sebagai bahasa kedua, seperti di Jerman, Norwegia, Swedia, Denmark, dan Belanda.

\section{f. Pengetahuan}

Bahasa Inggris adalah bahasa pengetahuan. Banyak informasi dikemas menggunakan Bahasa Inggris. Untuk itu, bagi kita yang ingin 
mendapat dan menguasai banyak pengetahuan, maka kita harus bisa Bahasa Inggris.

\section{g. Mudah}

Bahasa Inggris didasarkan oleh huruf alfabet yang sering digunakan sehari-hari. Jika dibandingkan dengan bahasa lain yang memiliki huruf-huruf tertentu, tentu belajar Bahasa Inggris akan lebih terasa mudah.

\section{h. Bahasa perfilman}

Dunia perfilman dunia didominasi oleh film yang menggunakan Bahasa Inggris. Jika kita menguasai Bahasa Inggris, kita tidak memerlukan penerjemah saat sedang menonton film berBahasa Inggris.

\section{i. Membuka kesempatan}

Fasih berbicara dalam Bahasa Inggris membuka berbagai kesempatan tanpa harus memerhatikan etnik, warna kulit, dan latar belakang.

\section{j. Belajar bersama}

Kita bisa mengajari Bahasa Inggris ke orang lain jika kemampuan Bahasa Inggris kita sangat baik.

Dari gambaran diatas dapat disimpulkan bahwa pentingnya bahasa Inggris karena bahasa Inggris dijadikan mata pelajaran di tingkat dasar sampai tingkat lanjutan. Bahasa Inggris juga diajar ditingkat perguruan tinggi sebagai mata kuliah wajib lulus. ini jelas sekali bahwa penguasaan bahasa inggris menjadi salah satu pengantar kesuksesan bidang akademik seseorang maupun dalam menunjang karir yang lebih baik.

\section{Faktor-faktor yang Mempengaruhi Proses Pembelajaran}

Masalah interaksi belajar mengajar merupakan masalah yang komplek karena melibatkan berbagai faktor yang saling terkait satu sama lain. Dari sekian banyak faktor yang mempengaruhi proses dan hasil interaksi belajar mengajar terdapat dua faktor yang sangat menentukan yaitu faktor guru sebagai subjek pembelajaran dan faktor peserta didik sebagai objek pembelajaran. Tanpa adanya faktor guru dan peserta didik dengan berbagai potensi kognitif, afektif, dan psikomotorik yang dimiliki tidak mungkin proses interaksi belajar mengajar dikelas atau ditempat lain dapat 
berlangsung dengan baik. Namun, pengaruh berbagai faktor lain tidak boleh diabaikan, misalnya faktor media dan instrument pembelajaran, fasilitas belajar, infrastruktur sekolah, fasilitas laboratorium, manajemen sekolah, sistem pembelajaran dan evaluasi, kurikulum, metode, dan strategi pembelajaran.

Kesemua faktor-faktor tersebut dengan pendekatan berkontribusi berarti dalam meningkatkan kualitas dan hasil interaksi belajar mengajar di kelas dan tempat belajar lainnya. Berikut akan dijelaskan pengaruh masingmasing faktor sebagai berikut:

Pertama, Media dan instrumen pembelajaran memiliki pengaruh dalam membantu guru mendemonstrasikan bahan atau materi pelajaran kepada siswa sehingga menciptakan proses belajar-mengajar yang efektif dengan kata lain media dipergunakan dengan tujuan membantu guru agar proses belajar siswa lebih efektif dan efisien. Fasilitas belajar yang tersedia dalam jumlah memadai di suatu sekolah memiliki pengaruh terhadap keberlangsungan proses belajar-mengajar. Tanpa ada fasilitas belajar yang tersedia dalam jumlah yang memadai di sekolah, proses interaksi belajarmengajar kurang dapat berjalan secara maksimal dan optimal.

Kedua, Metode pengajaran memiliki peranan yang penting dalam memperlancar kegiatan belajar mengajar proses belajar mengajar yang baik hendaknya mempergunakan berbagai jenis metode mengajar yang bervariasi. Dalam hal ini tugas guru adalah memilih berbagai metode yang tepat untuk menciptakan proses belajar mengajar yang efektif yang disesuaikan dengan tujuan pembelajaran.

Ketiga, Evaluasi atau penilaian berfungsi untuk mengetahui tercapai tidaknya tujuan pengajaran danuntuk mengetahui keefektifan proses belajar mengajar yang telah dilakukan guru. Tanpa adanya evaluasi guru tidak akan mengetahui hasil belajar yang dicapai oleh siswa dan tidak bisa menilai tindakan mengajarnya serta tidak ada tindakan untuk memperbaikinya.

\section{Faktor Terjadinya Problematika Pembelajaran}

Dimyati dan Sudjiono mengemukakan bahwa problematika pembelajaran berasal dari dua faktor yaitu faktor internal dan eksternal. 


\section{a. Faktor Internal}

Dalam belajar siswa mengalami beragam masalah, jika mereka dapat menyelesaikannya maka mereka tidak akan mengalami masalah atau kesulitan dalam belajar. Terdapat berbagi faktor internal dalam diri siswa, yaitu:

1) Sikap Terhadap Belajar

Sikap merupakan kemampuan memberikan penilaian tentang sesuatu, yang membawa diri sesuai dengan penilaian. Adanya penilaian tentang sesuatu, mengakibatkan terjadinya sikap menerima, menolak, atau mengabaikan.

2) Motivasi belajar

Motivasi belajar merupakan kekuatan mental yang mendorong terjadinya proses belajar.

3) Konsentrasi belajar

Konsentrasi belajar merupakan kemampuan memusatkan perhatian pada pelajaran.

4) Kemampuan mengolah bahan belajar

Merupakan kemampuan siswa untuk menerima isi dan cara pemerolehan ajaran sehingga menjadi bermakna bagi siswa. Dari segi guru, pada tempatnya menggunakan pendekatan-pendekatan keterampilan proses, inkuiri, ataupun laboratori.

5) Kemampuan menyimpan perolehan hasil belajar

Menyimpan perolehan hasil belajar merupakan kemampuan menyimpan isi pesan dan cara perolehan pesan. Kemampuan menyimpan tersebut dapat berlangsung dalam waktu pendek yang berarti hasil belajar cepat dilupakan, dan dapat berlangsung lama yang berarti hasil belajar tetap dimiliki siswa.

6) Menggali hasil belajar yang tersimpan

Menggali hasil belajar yang tersimpan merupakan proses mengaktifkan pesan yang telah diterima. Siswa akan memperkuat pesan baru dengan cara mempelajari kembali, atau mengaitkannya dengan bahan lama. 
7) Kemampuan berprestasi

Siswa menunjukkan bahwa ia telah mampu memecahkan tugastugas belajar atau mentransfer hasil belajar. Dari pengalaman seharihari di Sekolah bahwa ada sebagian siswa yang tidak mampu berprestasi dengan baik.

8) Rasa percaya diri siswa

Dalam proses belajar diketahui bahwa unjuk prestasi merupakan tahap pembuktian "perwujudan diri" yang diakui oleh guru dan teman sejawat siswa.

9) Intelegensi dan keberhasilan belajar

Dengan perolehan hasil belajar yang rendah, yang disebabkan oleh intelegensi yang rendah atau kurangnya kesumgguhan belajar, berarti terbentunya tenaga kerja yang bermutu rendah.

10) Kebiasaan belajar

Dalam kegiatan sehari-hari ditemukan adnya kebiasaan yang kurang baik. Kebiasaan belajar tersebut antara lain: belajar diakhir semester, belajar tidak teratur, menyia-nyiakan kesempatan belajar, bersekolah hanya untuk bergengsi, datang terlambang bergaya pemimpin dam lain sebagainya.

11) Cita-cita siswa

Dalam rangka tugas perkembangan, pada umumnya setiap anak memiliki cita-cita. Cita-cita merupakan motivasi intrinsik, tetapi gambaran yang jelas tentang tokoh teladan bagi siswa belum ada. Akibatnya siswa hanya berperilaku ikut-ikutan.

\section{b. Faktor Eksternal}

Proses belajar didorong oleh motivasi intrinsik peserta didik. Disamping itu proses belajar juga dapat terjadi, atau menjadi bertambah kuat, bila didorong oleh lingkungan peserta didik. Dengan kata lain aktivitas belajar dapat meningkat bila program pembelajaran disusun dengan baik. Program pembelajaran sebagai rekayasa pendidikan guru di sekolah merupakan faktor eksternal belajar. Ditinjau dari segi peserta didik, maka ditemukan beberapa faktor eksternal ang berpengaruh pada aktivitas belajar. Faktor-faktor eksternal tersebut adalah sebagai berikut: 
1) Guru sebagai pembina peserta didik dalam belajar

Sebagai pendidik, guru memusatkan perhatian pada kepribadian peserta didik, khususnya berkenaan dengan kebangkitan belajar. Kebangkitan belajar tersebut merupakan wujud emansipasi diri peserta didik. Sebagai guru, ia bertugas mengelola kegiatan belajar peserta didik di Sekolah. Guru juga menumbuhkan diri secara profesional dengan mempelajari profesi guru sepanjang hayat.

2) Sarana dan prasarana pembelajaran

Lengkapnya sarana dan prasarana pembelajaran merupakan kondisi pembelajaran yang baik. Lengkapnya sarana dan prasarana pembelajaran merupakan kondisi pembelajaran yang baik. Hal itu tidak berarti bahwa lengkapnya sarana dan prasarana menentukan jaminan terselenggaranya proses belajar yang baik.

3) Kebijakan penilaian

Keputusan hasil belajar merupakan puncak harapan peserta didik. Secara kejiwaan, peserta didik terpengaruh atau tercekam tentang hasil belajarnya. Oleh karena itu, Sekolah dan guru diminta berlaku arif dan bijak dalam menyampaikan keputusan hasil belajar peserta didik.

4) Lingkungan sosial peserta didik di sekolah

Peserta didik siswi di Sekolah membentuk suatu lingkungan sosial peserta didik. Dalam lingkungan sosial tersebut ditemukan adanya kedudukan dan peranan tertentu. Ada yang menjabat sebagai pengurus kelas, ketua kelas, OSIS dan lain sebagainya. Dalam kehidupan tersebut terjadi pergaulan seperti hubungan akrab, kerja sama, bersaing, konflik atau perkelahian.

5) Kurikulum Sekolah

Program pembelajaran di Sekolah mendasarkan diri pada suatu kurikulum. Kurikulum disusun berdasarkan tuntutan kemajuan masyarakat.

Dari gambaran diatas, dapat disimpulkan bahwa dalam proses pembelajaran memiliki faktor-faktor pendukung baik internal maupun eksternal guna tercapainya tujuan pembelajaran. 


\section{Karekteristik Mahasiswa}

Menurut kamus besar bahasa indonesia, mahasiswa adalah mereka yang sedang belajar di perguruan tinggi (Poerwadarminta, 2005: 375). Mahasiswa adalah manusia yang tercipta untuk selalu berpikir yang saling melengkapi (Dwi Siswoyo, 2007: 121). Mahasiswa dinilai mampu dan memiliki tingkat intelektualitas yang tinggi, kecerdasan dalam berfikir dan perencanaan dalam bertindak. Karakteristik mahasiswa secara umum yakni stabilitas kepribadian yang mulai meningkat, cenderung berfikir matang terhadap apa yang ingin dicapainya, lebih dekat dengan teman sebaya, mandiri dan memiliki pemikiran masa depan.

\section{Pembelajaran}

Pembelajaran berasal dari kata dasar "belajar" yang berarti sebuah proses, cara, perbuatan sehingga orang atau peserta didik belajar dan memperoleh ilmu pengetahuan. Jadi kata pembelajaran adalah suatu proses belajar mengajar (PBM) yang merupakan keterpaduan antar kegiatan guru sebagai pengajar dan kegiatan peserta didik sebagai pelajar sehingga terjadi saling interaksi keduanya dalam situasi instruksional yang bersifat pengajaran.

Oemar Hamalik mengemukakan bahwa pembelajaran merupakan kombinasi yang tersusun meliputi unsur-unsur manusiawi, material, fasilitas, perlengkapan dan prosedur yang saling mempengaruhi untuk mencapai tujuan pembelajaran (Oemar Hamalik, 2011:57). Material meliputi buku-buku, papan tulis, media pembelajaran. Fasilitas meliputi ruang kelas dan perlengkapannya sedangkan prosedur, meliputi jadwal metode pengajaran dan ujian. Selain itu dalam mencapai tujuan pembelajaran perlu adanya komponen pendukung pembelajaran yang lain. Menurut Suyanto dan Djihad Hisyam komponen-komponen pembelajaran tersebut harus mampu berinteraksi dan membentuk sistem yang saling berhubungan, sehingga mampu menciptkaan proses pembelajaran yang berkualitas (Suyanto dan Djihad Hisyam, 2010: 81).

Adapun komponen yang mempengaruhi berjalannya suatu proses pembelajaran dalam kegiatan belajar mengajar adalah beberapa komponen pembelajaran yang saling berkaitan antara satu dengan yang lainnya yaitu: 
1) guru, 2) peserta didik, 3) materi pembelajaran, 4) metode pembelajaran,

5) media pembelajaran, 6) evaluasi pembelajaran. Adapun ciri-ciri pembelajaran menurut Oemar Hamalik, yakni:

a. Rencana meliputi penataan ketenagaan, materi dan prosedur yang merupakan unsur-unsur sistem pembelajaran dalam suatu rencana khusus;

b. Saling ketergantungan antara unsur-unsur sistem pembelajaran yang serasi dalam suatu keseluruhan.

c. Pembelajran memiliki tujuan tertentu yang hendak dicapai (Oemar Hamalik, 2002: 66).

Pembelajaran merupakan sebuah proses menjadikan peserta didik lebih baik yang didukung oleh pendidik serta menyelenggarakan komponen pembelajaran dengan baik.

Penelitian ini menggunakan metode deskriptif kualitatif Sugiono juga mengemukakan penelitian kualitatif sebagai metode penelitian yang berlandaskan pada filsafat postpositivisme, digunakan untuk meneliti pada kondisi objek alamiah, dimana peneliti adalah sebagai instrumen kunci, teknik pengumpulan data dengan triangulasi, analisis data bersifat induktif atau kualitatif, dan hasil penelitian kualitatif lebih menekankan makna daripada generalisasi (Sugiono, 2012: 9) . Penelitian ini dilaksanankan di Sekolah Tinggi Agama Islam Negeri Bengkalis. Penelitian ini dimulai pada bulan Agustus sampai Oktober 2018. Subjek penelitian ini adalah mahasiswa semester 3 (tiga) STAIN Bengkalis dan objek penelitian menganalisa problematika dalam pembelajaran Bahasa Inggris. Populasi penelitian berjumlah 310 orang. Peneliti mengambil sampel secara acak. Teknik pengambilan sampel ini dinamakan simple random sampling. Pengambilan sampel acak sederhana dapat dilakukan dengan cara undian, memilih bilangan dari daftar bilangan secara acak. Hasil penelitian dapat disimpulkan sebagai berikut:

a. Gambaran permasalahan pembelajaran bahasa Inggris dilihat dari segi faktor internal pada mahasiswa STAIN Bengkalis yakni dipengaruhi oleh (1) sikap terhadap belajar; (2) motivasi belajar; (3) konsentrasi belajar; 
(4) intelegensi dan keberhasilan belajar; (5) kebiasaan belajar; (6) kemampuan mengolah bahan belajar (7) kemampuan berprestasi.

b. Gambaran permasalahan pembelajaran bahasa Inggris dilihat dari segi faktor eksternal pada mahasiswa STAIN Bengkalis yakni dipengaruhi oleh Sedangkan faktor eksternal dipengaruhi oleh pendidik yaitu dosen yang mengajar bahasa inggris kurang bervariasi dalam mengajar.

\section{Simpulan}

Pada dasarnya, faktor internal dan eksternal dari responden memberikan respon positif dimana banyak pilihan tertuju kepada Setuju.Secara umum, responden menyukai pelajaran bahasa inggris karena cara mengajar dosen yang menyenangkan, dosen menggunakan metode yang bervariasi, dan suasana belajar yang menyenangkan.Adanya sarana dan prasarana yang memadai menjadi salah satu faktor dalam belajar bahasa Inggris sehingga mereka tidak menghadapi masalah dalam proses pembelajaran.Responden sangat menyadari bahwa belajar bahasa inggris merupakan satu kebutuhan karena bahasa inggris menjadi bahasa internasional. Dari kuisioner yang disebar ke responden faktor internal lebih dominan dalam kesuksesan dalam belajar. 


\section{Daftar Pustaka}

Majid, Abdul. 2014. Strategi Pembelajaran. Bandung: Rosdakarya.

Debdikbud. 2002. Kamus Besar Bahasa Indonesia, Jakarta : Bulan Bintang.

Siswoyo, Dwi. 2007. Ilmu Pendidikan, Yogyakarta: UNY Pers.

Dimyati dan Mudjiono. 2010. Belajar dan Pembelajaran, Jakarta: Rineka Cipta

Hermayawati. 2010. Analisis Kesulitan Belajar Bahasa Inggris Mahasiswa; Journal Sosio-Humaniora vol.1 No.1 September 2010, ISSN: 2087-1899

Muh Rosihuddin, Pengertian Problematika Pembelajaran, dalam http: //banjirembun.blogspot.com /2012/11/pengertian-problematikapembelajaran. html. 28 April 2015.

Syah, Muhibbin. 1997. Psikologi Pendidikan dengan Pendekatan Baru, Bandung: Rosdakarya.

Mundofir, Problematika Pembelajaran Bahasa Indonesia pada Kurikulum 2013 di SMAN 6 dan SMA Negeri 7 Banjarmasin.

Hamalik, Oemar. 2008. Kurikulum dan Pembelajaran, Jakarta: Bina Aksara.

Hidayat, Nandang Sarip. 2012. Problematika Pembelajaran Bahasa Arab, Akademika, Vol. 37, No. 1 (Januari-Juni 2012).

Poerwadarminta, W.J.S. 2005. Kamus Umum Bahasa Indonesia. Edisi Ketiga, Jakarta: Balai Pustaka.

Muchith, Saechan. 2008. Pembelajaran Kontekstual, Semarang: Rasail Media Group.

Sugiyono. 2012. Statistika Untuk Penelitian, Bandung: Alfabeta

Suyanto dan Djihad Hisyam. Refleksi dan Reformasi Pendidikan Indonesia Memasuki Millenium III. Yogyakarta: Adi Cita

Lubis, Tasnim. 2017. Faktor yang Mempengaruhi Kesulitan Mahasiswa Dalam Menyelesaikan Daily English Vocabularydi Politeknik LP3i. Journal Bisnis Administrasi Volume 06 Nomor 01.

Zaenudin H.R.L, dkk. 1997. Pusat Sumber Belajar. (Jakarta: Dirjen PT. Dep. T dan $\mathrm{K}$.

Zamrud Whidas Pratama. 2014. Faktor-faktor Kesulitan Mahasiswa Dalam Pembelajaran PIM 3 Vokal di Jurusan Pendidikan Seni Musik FBS UNY. 